\title{
Positive Expectations: A Reflective Tale on the Teaching of Writing
}

\author{
Lolly Ockerstrom, PhD \\ Assistant Professor of English \\ Park University
}

\begin{abstract}
A case study on the teaching of writing, this paper discusses what motivates students in a freshman writing course to complete increasingly difficult writing assignments. The study provides a glimpse into how one class of freshman students developed positive expectations for writing a paper about a difficult poem by helping each other map strategies for reading and writing.
\end{abstract}

\section{Introduction}

“We are not researchers in other people's classrooms... but reflective practitioners in our own classrooms, searching for insights that will help us understand and improve our practice."

-Glenda Bissex, Partial Truths

As the fall term approached, and I worked on my syllabus for English 105, I concentrated on two intertwining goals: 1) to motivate students to engage in reflective learning, and, 2 ) to help students develop positive expectations for their writing. To accomplish these goals, I needed to create assignments that would provide the students with opportunities to work together to write, revise, and reflect. I also needed to spend less time talking and more time observing in the classroom in order to understand how students learn. Although I did not think at the time that I was planning a case study, as classes got underway and I developed a more intentional approach to my teaching, I realized I was seeing through the lens of a

Not only did I want the students to become more self-reflective and positive, but I wanted to achieve that myself as well. teacher-researcher. Not only did I want the students to become more self-reflective and positive, but I wanted to achieve that myself as well.

Glenda Bissex writes that case study research "requires a certain frame of mind-a readiness to hear and to see, a capacity for suspending, or being jolted out of, our usual interpretations of classroom events" (192). It was this "certain frame of mind" that I wanted to nurture in order to help create a positive atmosphere where every student felt that what they did (and what they did not do) mattered.

\section{English 105 and Writing Assignments}

English 105, the first freshman writing course at Park University, introduces students to the writing process, focuses on personal writing to explore academic questions, and places heavy emphasis on revision. I assign three major essays, and numerous shorter pieces written both in and out-of-class, sometimes asking students to read short nonfiction essays as a prompt. Occasionally I use a piece of literature as a prompt, although it is not a course in writing about literature.

Each student develops a portfolio of writing, which includes a reflective essay written at the end of term. One important outcome of writing portfolios, as Jeffrey Sommers has written, is to "encourage students to revise because it suggests that writing occurs over time, not in a single sitting" (154). Portfolios also increase motivation, particularly since students have some choice about what to include. Finally, the use of portfolio assessment helps students engage in selfreflection, and helps them develop critical thinking. In their essay, "Metacognition 
and the Use of Portfolios," Karen Mills-Courts and Minda Rae Amiran explain how portfolios are used as both a pedagogical tool, and an assessment tool:

Most of the best research on cognitive development suggests that it is extremely important to create situations in which students must think about their own thinking, reflect on the ways in which they learn and why they fail to learn...lt's clear that the more students are aware of their own learning processes, the more likely they are to establish goals for their education and the more deeply engaged they are in those processes (103).

To take this one step further, the more students grasp why something is difficult for them, the more insight they gain, the less mysterious academic inquiry is for them, and the more motivated they become to engage in learning. Some of the most compelling writing I have seen in student portfolios is when the student analyzes why he or she had difficulty with a particular assignment.

For the class, I design progressively more challenging writing assignments throughout the semester. However, I always embed questions and opportunities for discussion that help students relate the material to their own lives. Barbara Davis, a theorist on motivation, has written, "whatever level of motivation your students bring to the classroom will be transformed, for better or worse, by what happens in that classroom" (1). She goes on to note, "good everyday teaching practices can do more to counter student apathy than special efforts to attack motivation directly" (1). This means that at the beginning of the semester students need opportunities to succeed in order to bolster their self-confidence and willingness to take risks, which results in learning.

Therefore, in the second week of the term, I assign a paper on "My History as a Reader and a Writer" as the first major assignment. Students are asked to think about favorite childhood books and focus on their own experiences reading and writing. They see themselves (perhaps for the first time) as accomplished scholars. Many express surprise at recalling so much about their childhood, the books they read, and learning to write. Some recall unpleasant memories about feeling humiliated in class, and not wanting to read or share their writing with anyone as a result. Remembering and writing about these early experiences, they begin to make important connections between their early experiences as readers and writers and their current attitudes toward reading and writing as college freshmen.

The second major assignment is open choice, with parameters governing audience, purpose, and scope. This open

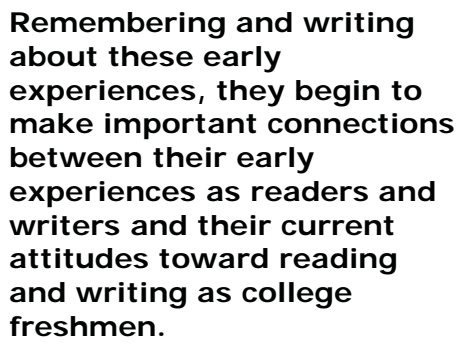

choice assignment provides students with control over the assignment, which increases their level of engagement and motivation. For some students, however, this assignment presents deep challenges, since they must make their own decisions about what to write. Some express surprise at how uneasy they feel without the usual guidelines governing topic choice. One-on-one conversations with such students help them through this uncharted territory. They also work in groups to discuss their ideas prior to writing. Often they simply need encouragement to develop their ideas, and permission to write on topics they didn't think were academic enough. Such open-ended assignments help students to develop as writers, as they are faced with making important choices on such issues as point of view, focus, and the use of detail.

With all assignments, students have the option to work on their papers independently, with one other person, or in groups. This element of choice, while small, nonetheless increases both engagement and motivation. Donald Murray, a

InSight: A Collection of Faculty Scholarship 
Pulitzer Prize winning journalist and former professor of writing, describes practical advice on helping to motivate student writers in $A$ Writer Teaches Writing. He advocates simple enthusiasm for student accomplishments and sharing excitement about writing and reading. He admonishes teachers of writing to accept each "student's own writing goals...and helping that student achieve the goal" (231). It's like handing over the car keys; it shows you trust them. If students know you take them seriously, they will take themselves seriously, and in

\author{
If students know you take \\ them seriously, they will \\ take themselves seriously, \\ and in turn, they will take \\ their writing seriously.
} turn, they will take their writing seriously.

The third major essay assignment I require usually involves some kind of reading. Although I normally assign a piece of nonfiction prose, last fall I decided to assign "The Rime of the Ancient Mariner," written in two versions in 1798 and 1817 by English poet, Samuel Taylor Coleridge. I wanted the class to read something challenging, and something from an earlier century in order to give them some sense of tradition and genre in writing. I drew from the work of both Glenda Bissex, who asks for students to read and write associative responses to poetry rather than literary analysis, and Kathleen Blake Yancey, who asks students to read and explore what they do not understand. Both rely on close readings of texts. Yancey writes:

Not-understanding is not an absence, but rather an acquired art. As students learn, articulating what they don't understand is a critical first move toward a fuller, more complex understanding... We...read...as far as we can. We start with what we do understand, spending the time we might otherwise have spent asserting that we can't understand...we read, taking the poem as far as we can, and then trying to see how and why we get derailed (45).

When I gave the assignment to read "The Rime of the Ancient Mariner," I told the class that I did not expect the poem to be the primary focus of the paper, suggesting instead that students relate the poem to their reading experience or to some event in their own lives. When explaining the assignment, students received written directions to simply read the entire poem over the weekend, perhaps take a few notes, but not to do any writing until we discussed the poem in class. They were to bring one comment about it to the next class. I suggested they write down their initial thoughts, which might include questions about the poem, to prepare for class discussion.

When I urged them to have fun reading the poem, I could tell by the way they rolled their eyes they thought I had gone too far. We all laughed, and I warned them that the poem was indeed strange and challenging, but that in the next class we would discuss the poem, and brainstorm orally in class as well as write brainstorming lists of ideas that might be developed into a paper. My expectations in assigning Coleridge's poem were high but realistic. As Barbara Davis notes, such expectations mean that "your standards are high enough to motivate students to do their best work but not so high that students will inevitably be frustrated in trying to meet those expectations" (2). By setting up incremental steps, I hoped to provide opportunities for student success, and prevent them from feeling discouraged by the assignment. I also shared my own enthusiasm for Coleridge's poem.

\section{"I don't know what to write!"}

In the next class, I asked the students what they thought of the poem. When I realized that no one was willing to look at me, let alone volunteer an opinion, I asked how many had been able to read the poem. Had it been difficult? 
Did they like it? What did they think? Hands went up, and slowly students began to volunteer.

Many claimed that they "hated" poetry and didn't see the point of having to read and write about it. After all, as Sharon noted early in the conversation, "It has nothing to do with my life." Most students thought the main problem was the language of the poem. To them, it was "old English." Not only individual words, but the phrasing and word order were to them "old fashioned" and "hard to understand." Since Coleridge had deliberately used language that was archaic even in his day when writing "The Rime," the students' reactions were actually pretty close to reality, and I pointed this out to them. Surprised to receive praise for their observation, they appeared to feel relieved knowing that they hadn't gotten it all wrong.

Dawn said simply, "I don't know what to write about. I read the whole poem, but I still don't understand it and I just don't know what to write about." It was obviously too soon for her, and others, to write about the poem when reading it was still an obstacle. I suggested that we talk more about our reading process. Some had tried to read it at night in bed, some had tried to look up every word they didn't know in a dictionary, others had simply closed the book intending to try again later. All had engaged in some kind of reading strategy, though without the positive outcome they had hoped for.

"Did anyone read the poem aloud?" I asked. Only two hands went up, and everyone else looked surprised.

"Why did you read aloud?" I asked, "and what happened when you did that?"

And then the best happened: Alicia, who seldom spoke in class, noted that although the poem was difficult for her, she remembered having read portions of the poem aloud when she studied it in high school, which had helped her get a better sense of what was happening in the poem. Since the technique helped her in high school, she tried it again this time.

\section{The Flood Gates Open}

Suddenly, the students could not volunteer fast enough to tell of their experiences reading the poem. They talked about where they read the poem, how many times they read it, what lines were particularly difficult or memorable. We talked about what "happened" in the narrative poem, who the characters were, what the mood was, and what they thought the albatross was.

"... and then," said Alicia, "when I started realizing what was happening in the poem, I thought, 'this won't be so bad to write about.' And I looked at the homework assignment you gave us, and I thought, oh, I can do number 3: write about a time when I experienced something kind of spooky, or supernatural."

Although her account was brief, she recounted her study practices, sharing both self-reflection and meta-cognition, all higher-order learning practices. As she spoke, I saw lights go on in the eyes of most of the other students. They were not just listening, but actually hearing Alicia talk about her experience, and they were learning from it. They also began to shed some of their inhibitions as they realized that it was okay if they didn't understand

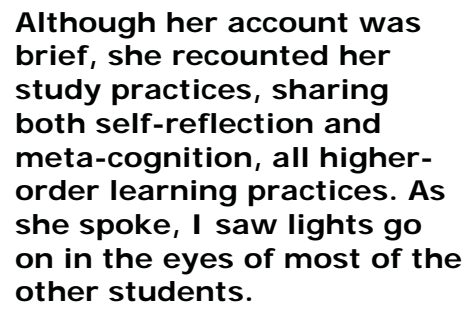

everything. By now, the class was having a genuine conversation with each other about learning, using their own experiences with the poem. They described what they did when they read the poem, and talked about how they read, rather than focusing only on what they read.

Although now Alicia was teaching the class, neither she nor the rest of the class realized it. What they did realize is that they had broken through a difficult 
barrier in reading the poem and had made personal connections to it. Dawn asked, "You mean I could write about how I read the poem? Would that be okay?"

I responded, "Yes, that would be one way to approach the assignment."

Ted volunteered, "Well, actually, the ancient mariner made me think about my grandpa. He was a mariner in the China Sea and I thought I could write about how the poem made me think about him. Would that work?"

By the time class ended, almost everyone had expressed at least a fragment of an idea for the paper. Motivated by hearing Alicia's story, Dawn's question, and Ted's idea about his grandpa, they became engaged in the assignment, eagerly exchanging ideas with one another. No one mentioned grades, only ideas. Now fully engaged in what Paolo Freire calls "problem-posing education," they had developed, as Freire writes,

their power to perceive critically the way they exist in the world with which and in which they find themselves; they come to see the world not as a static reality, but as a reality in process, in transformation.... and thus establish an authentic form of thought and action (328, Freire's italics).

Learning that there were many ways to address the assignment, they gained self confidence, which stimulated more ideas. They returned to the next class period with the beginnings of a rough draft, eager to talk about their ideas. Joe was delighted to report that after reading the poem he now knew the source of "Water, water every where,/ nor any drop to drink" (Coleridge 35 II. 121-122), lines he had heard previously, but for which he had not had a context. Others nodded agreement, and expressed satisfaction that they could now tell others the origin of those lines.

They had done what they thought

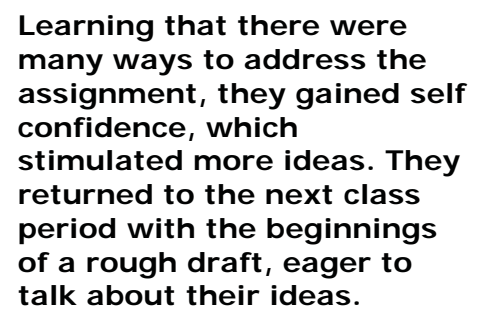

they couldn't do: they had read the poem, realized it was okay not to understand everything about it, and had begun to write lists or rough drafts. They had accomplished a great deal. As their tentative drafts became more concrete, their voices became more authentic, and their writing became more honest. Sharon wrote:

\begin{abstract}
What I ended up finding out was that the poem wasn't as bad as I made it out to be. It was bearable.... [What] helped me to understand the poem was the class discussion we had about the poem. Everyone shared their thoughts and ideas about it. To me this was helpful. It let me know what others thought about the poem and I figured out that I was not the only one who didn't understand it or like it. Everyone had their own thoughts about this poem and how they perceived it. Everyone related to this poem, but in a different way.... The Rime of the Ancient Mariner was not something I enjoyed reading, but it wasn't something I should have dreaded to read. It was better than I gave it credit for (Unpublished Student Paper).
\end{abstract}

For Sharon, the class discussion remained key to her understanding of the poem. Although she did not like "The Rime of the Ancient Mariner," she learned that it "wasn't as bad" as she thought, and that she should not have "dreaded" reading it. Her shift from negative to neutral assessment illustrates a major shift in her understanding of the assignment and helped establish for her a sense of positive expectation about her ability to write her paper. While she hasn't opened the door completely, it does not appear to be closing anytime soon.

54 Volume 2, Student Motivation, 2007 


\section{End-of-Term Portfolios}

By the end of the term, the students had written and revised their essays many times. As students came to my office to hand me their portfolios, many said proudly: "I didn't realize how much writing I had done this term!"

The reflective essays revealed how much these students had learned about themselves and about the various stages of invention, writing, and revision. They included powerful and genuine stories about freshman students developing academic habits of mind as they crossed the border from high school to college. Sam's reflective essay ends with an assessment of how and why his attitude changed in the course:

For the first time since I don't know when, I feel like I have received an education in the course, versus a letter grade. Usually I finish classes and get a decent passing grade, but feel none the wiser. This course actually surprised me and I feel like I gained more from this course than any other I took this semester. I'm really not trying to exaggerate things to suck-up; I'm being onehundred percent honest about this. I had low expectations for this class because of previous experiences in writing classes. I'll even admit that towards the middle of the semester I felt I was learning nothing at all, when I was and I just didn't realize it. Most of what I was learning was how to write better papers, and I just wasn't paying attention to what I was accomplishing. The goal of college is to get an education, and be more informed. This feeling of getting educated is so much of a better feeling than an " $A$ " grade I've ever received. I'm glad I've taken this course and feel confident in moving to the next level of classes (Unpublished Student Paper).

Sam's initial low expectations for the class echo Sharon's low expectations for "The Rime of the Ancient Mariner." Both writers speak confidently and honestly in authentic student voices. Sam's essay shows positive expectations for moving forward with his education, and makes a clear distinction between receiving high grades and acquiring an education. His paper also speaks to the impact of positive encouragement in motivating students to achieve their best.

In reading these and other reflective papers that came out of that class, I was humbled by each student's capacity for reflection and expression, and by their willingness to write about their own vulnerability as learners. They were often harder on themselves than I expected. Not all the students presented " $A$ " portfolios, but at this point that mattered less than the confidence with which they wrote their final essays. It was clear to me that they were ready to move on. While their writing showed varying levels of competency in using the conventions of written English, all illustrated young writers at work unafraid to

In reading these and other reflective papers that came out of that class, I was humbled by each student's capacity for reflection and expression, and by their willingness to write about their own vulnerability as learners.

write and willing to test their voices in an academic setting. Best of all, their essays actually said something. None of them were trying, to use Sam's words, to "suck up."

Ken Bain writes in his study of what the best teachers practice, "We will not reach all students equally, but there is something to learn about each one of them and about human learning in general" (174). Through reflective teaching, individual students became more defined, the classroom became more energized, and students became more motivated. As I studied my classroom, I re-learned the 
obvious: if you ask your students to become self-reflective, you must also ask it of yourself. No matter what or when you teach, if your teaching practices are selfreflective, you are researching, or as Glenda Bissex notes, you are re-seeing. The more I re-searched my classroom the more clearly individual students' stories emerged. And that is what it comes down to: individual students and what helps them learn (and want to learn). "The process of observing even a single individual," writes Bissex, "sensitizes us that much more to other individuals" (172). That is an obtainable and worthy goal, with positive implications for student motivation.

\section{Work Cited}

Bain, Ken. What the Best College Teachers Do. Cambridge: Harvard UP, 2004.

Bissex, Glenda. Partial Truths: A

Memoir and Essays on Reading,

Writing, and Researching.

Portsmouth, NH: Heinemann, 1996.

Coleridge, Samuel Taylor. The Rime of the Ancient Mariner. Ed., Paul $\mathrm{H}$. Fry. Boston: Bedford/St. Martin's, 1999.

Davis, Barbara Gross. "Motivating Students." 1 September 1999. <http://honolulu. hawaii.edu/intranet /committees/FacDevCom/guidebk/te achtip/motiv.htm>.

Freire, Paulo. "The Banking Concept of Education" A World of Ideas: Essential Readings for College
Writers. Ed. Lee A. Jacobus. Boston: Bedford/St. Martin's, 2006. 315-333.

Murray, Donald M. A Writer Teaches Writing, 2nd ed. Boston: Houghton Mifflin, 1985.

Sam. Unpublished Student Paper. English 105. Park University, Fall 2006.

Sharon. Unpublished Student Paper. English 105. Park University, Fall 2006.

Sommers, Jeffrey. "Bringing Practice in Line with Theory: Using Portfolio Grading in the Composition Classroom." Portfolios: Process and Product. Ed. Pat Belanoff and Marcia Dickson. Portsmouth, NH: Boynton/Cook Publishers, 1991.

Note: Names of students have been changed to protect the privacy of the students.

Ockerstrom joined the Park University faculty in 2004 after previously having taught at Virginia Commonwealth University (Richmond, Virginia) and Northeastern University (Boston, Massachusetts). She has also taught at a Quaker girls' school in Tokyo, Japan. She served as Writing Center Director at Northeastern, where she also received her Ph.D. Her publications include "Teaching with a Purpose" (Boston: Houghton-Mifflin), and conference presentations, including the Oxford Round Table on Women's Rights in the University of Oxford, England, and the International Virginia Woolf Society. She currently serves as Program Coordinator for Writing at Park, and is working on a creative non-fiction book about a World War II English war bride. 